$\begin{array}{ll}\begin{array}{l}\text { No vote } \\ \text { German council } \\ \text { snubs European } \\ \text { neutron source } \\ p 262\end{array} & \begin{array}{l}\text { Too few crew } \\ \text { Scaled-down space } \\ \text { station 'cannot do } \\ \text { high-prionity science' } \\ p 263\end{array}\end{array}$

\title{
Government spending promise offers British research a boost
}

David Adam and Natasha McDowell, London British researchers enjoyed some rare sunshine this week, as summer finally arrived and the government announced a $\mathfrak{E} 1.25$ billion (US\$2-billion) increase in annual science funding over the next three years.

Gordon Brown, the Chancellor of the Exchequer, announced on 15 July that the science budget at the Department of Trade and Industry (DTI) - which supports most British university research - will grow from

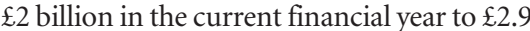
billion in 2005-06. The hike includes an extra $\mathfrak{1} 400$ million a year for research grants by the end of that period, as well as $\mathfrak{1} 100$ million to raise salaries for young researchers. There will also be fresh funds to renovate university labs.

Researchers and lobby groups have welcomed the pledge, part of a $\mathfrak{E} 60$-billion spending package in the public services. The spree is seen as an effort by the Labour government to commit to stronger public services, after five relatively austere years in office.

The science budget will grow by about $10 \%$ in real terms each year over the next three years (see chart), compared with $7 \%$ in the 1998 and 2000 reviews. The individual research councils that distribute the funds

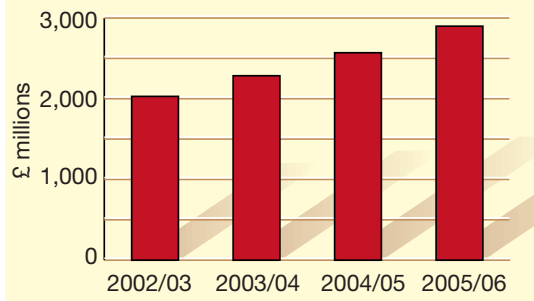

Spending spree: Gordon Brown has pledged to increase funds for research supported by the DTI.

won't discover their shares until later this year.

"There is substantial new money and importantly much of it is aimed at solving some of the long-term problems suffered by the science research base," says Peter Cotgreave, director of the pressure group Save British Science. The increased funding remains merely a promise, but Cotgreave says he is confident that the government will deliver, "even under the most pessimistic predictions about the economy".

Within the Department of Trade and Industry's enlarged science budget, the research councils will also receive $\mathfrak{E} 120$ million extra by 2005-06 to pay overheads for

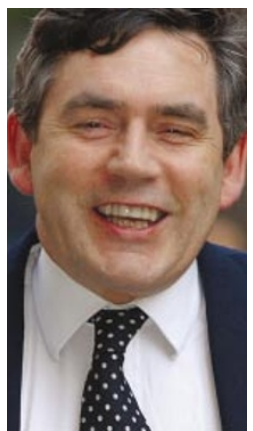

research grants, as well as new funding to help researchers set up spinoff companies. And the Department for Education and Skills will

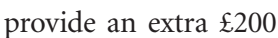
million annually, by the end of the period, for university equipment and buildings.

Under the plan, Brown estimates that the average $\mathrm{PhD}$ grant will grow from $\mathfrak{E} 10,000$ a year to $\mathfrak{E} 13,000$, while the wage of a postdoctoral research fellow will increase by $£ 4,000$ to $£ 21,000$ a year.

The pledge did not cover research done in other government departments, such as the Ministry of Defence and the Department for Environment, Food and Rural Affairs.

Separately, the Wellcome Trust, Britain's largest biomedical charity, announced a new

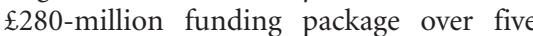
years. The plan will include money to extend the Sanger Centre near Cambridge and to help the government build a national centre charged with improving science teaching.

\section{California lab fires physicist over retracted finding}

\section{Rex Dalton, San Diego}

The Lawrence Berkeley National Laboratory (LBNL) in California has fired a physicist for allegedly fabricating data that contributed to a 1999 article on the purported discovery of two heavy elements.

Victor Ninov was fired in May after a year of internal probes into claims of scientific misconduct involving the apparent discovery of elements 118 and 116, reported in Physical Review Letters (V. Ninov et al. Phys. Rev. Lett. 83, 1104; 1999). Physical Review Letters formally retracted the article on 15 July, although Ninov's co-authors withdrew their support a year ago.

Ninov, who could not be reached for comment, has filed a grievance with the
University of California, which manages the LBNL for the Department of Energy (DOE), says Pier Oddone, the LBNL's deputy director. Ninov, who was in charge of computer analysis of the experiments, denies fabricating any data, says Oddone.

None of Ninov's 14 co-authors on the article were engaged in data fabrication, says Oddone. The data in question involved a computer analysis of an experiment in which high-energy krypton ions were fired at a lead target in the LBNL's cyclotron.

But questions are being raised in Germany about Ninov's work in two earlier articles, published while he was working at the GSI, a national research institute in Darmstadt.

The European Physical Journal A published an article this month (S. Hofmann et al. Eur. Phys. J. A 14, 147-157; 2002) discussing repeat experiments of the previously reported discoveries of elements 111 and 112 (S. Hofmann et al. Zeitschrift fur Physik A 350, 277-280; 1995, and S. Hofmann et al. Z. Phys. A 354, 229-230; 1996). Ninov did analysis at the GSI for the 1995 and 1996 papers, researchers say.

The European Physical Journal A article alleges that there were two instances in which raw data from the earlier experiments did not match the published results. Results "were spuriously created", wrote GSI physicist Sigurd Hofmann, lead author in all three articles. But the discovery of elements 111 and 112 still stands, he wrote. 